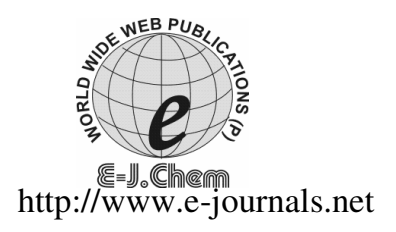

ISSN: 0973-4945; CODEN ECJHAO

E-Journal of Chemistry

2011, 8(1), 153-158

\title{
Synthesis and Study of Mixed Ligand-Metal Complexes of 1, 3, 7-Trimethylxanthine and 1, 3-Dimethyl-7H-purine-2, 6-dione with Some Other Ligands
}

\author{
SHAYMA A. SHAKER \\ Department of Engineering Sciences and Mathematics \\ College of Engineering, Universiti Tenaga Nasional \\ KM 7 Jalan Kajang- Puchong, 43009 Kajang, Selangor, Malaysia \\ drshaimaa611@yahoo.com
}

Received 24 June 2010; Accepted 2 September 2010

\begin{abstract}
This work presents synthesis and study of a new mixed ligand metal complexes of 1,3,7-trimethylxanthine and 1,3-dimethyl-7 $\mathrm{H}$-purine-2,6-dione with some other ligands like SCN and $\mathrm{OCN}$ ions to give the general formula $\left[\mathrm{M}(\mathrm{Tx})_{2}(\mathrm{Tp})_{2} \mathrm{XY}\right]$ where $\mathrm{M}=\mathrm{Co}(\mathrm{II}), \mathrm{Ni}(\mathrm{II}), \mathrm{Cu}(\mathrm{II}), \mathrm{Zn}(\mathrm{II})$ and $\mathrm{Cd}(\mathrm{II}), \mathrm{Tx}=1,3,7-$ trimethylxanthine, $\mathrm{Tp}=1,3$-dimethyl-7H-purine-2,6-dione, $\mathrm{X}=\mathrm{SCN}$ and $\mathrm{Y}=$ OCN. The resulting products were found to be solid which have been characterized using UV-Visible and infrared spectroscopy. Elemental analyses were performed using $\mathrm{C}, \mathrm{H}, \mathrm{N}$ analysis and atomic absorption techniques. The magnetic susceptibility and the conductivity were also measured. The present results suggest that the 1,3,7-trimethylxanthine and 1,3-dimethyl-7 $\mathrm{H}$-purine2,6-dione were coordinated with metal ions through the nitrogen atom. Thiocyanate ion was coordinated with metal ions through the sulfur atom and the cyanate ion was coordinated with metal ions through the oxygen atom.
\end{abstract}

Keywords: 1,3,7-Trimethylxanthine complexes, 1,3-Dimethyl-7H-purine-2,6-dione complexes, Mixed ligand complexes, Thiocyanate complexes, Cyanate complexes.

\section{Introduction}

The purine bases (constituents of the nucleic acids) are playing an important role of biological activity. In last few years the interaction of metal ions with nucleic acids has been very active area of inorganic and structural chemistry ${ }^{1}$. Thus, methylxanthine derivatives as possible inhibitor leads are also used therapeutically as anti-inflammatory agents, considered corrosion inhibition capability and they have significant efficiency as a non-toxic. Moreover, these derivatives are competitive inhibitors against a fungal family 18 chitinase. The enzyme 
assays has also revealed that these methylxanthines are active against human chitinases ${ }^{2-4}$. The early studies indicated that the 1,3,7-trimethylxanthine ingestion could result in both increase and decrease in different individuals but more recent studies have confirmed the average increased delta activity with 1,3,7-trimethylxanthine. Thus, some studies were evaluated the possibility of the synergistic effects of the selected antibiotics with 1,3,7trimethylxanthine against Staphylococcus aureus ${ }^{5}$.

The study of metals coordination with the purines reveals in vitro the mechanism of their coordination with $\mathrm{DNA}^{6}$. The most studies on complexes have shown that the unsubstituted purines normally coordinated to the metals via imidazole nitrogen atom ${ }^{7}$. In this work, the interaction of 1,3,7-trimethylxanthine and 1,3-dimethyl-7 $\mathrm{H}$-purine-2,6-dione with metal ions $\mathrm{Co}(\mathrm{II}), \mathrm{Ni}(\mathrm{II}), \mathrm{Cu}(\mathrm{II}), \mathrm{Zn}(\mathrm{II})$ and $\mathrm{Cd}(\mathrm{II})$ is investigated.

\section{Experimental}

All chemicals were obtained from commercial sources and were used without further purifications $\left(\mathrm{CoCl}_{2} \cdot 6 \mathrm{H}_{2} \mathrm{O}, \mathrm{NiCl}_{2} \cdot 6 \mathrm{H}_{2} \mathrm{O}, \mathrm{CuCl}_{2} \cdot 2 \mathrm{H}_{2} \mathrm{O}, \mathrm{ZnCl}_{2}, \mathrm{Cd}\left(\mathrm{NO}_{3}\right)_{2} \cdot 4 \mathrm{H}_{2} \mathrm{O}, \mathrm{KOCN}\right.$ and $\mathrm{KSCN}$ ) from Riedeal-Dehaenage. 1,3,7-trimethylxanthine and 1,3-dimethyl-7H-purine-2,6dione were obtained from $\mathrm{BDH}$, methanol, ethanol and dimethylsulfoxide from Fluka. The I.R spectra in the range of $4000-400 \mathrm{~cm}^{-1}$ were recorded as potassium bromide disc on a Shimadzu FTIR-8300 Fourier transform infrared spectrophotometer. UV-Visible spectra were measured in dimethylsulfoxide (DMSO) using Shimadzu UV-Visible recorder spectrophotometer UV-160. Elemental analysis (C, H, N) was performed by the micro analytical unit on a Berkin Elemer B-240 Elemental Analyzer. Determinations for metals were carried out using gravimetric methods. Conductivity measurements were carried out at $25{ }^{\circ} \mathrm{C}$ in DMSO using Philips Pw-9526 digital conductivity meter. Melting point was determined using a Stuart-Melting Point Apparatus. The magnetic susceptibility measurements were eventually obtained using a Balance Magnetic Susceptibility Balance Model MsB-MK1.

\section{General procedure for synthesis}

An ethanolic solution (12 mL) of 1,3,7-trimethylxanthine (Tx) (1.43-2.66 g) and an ethanolic solution $(15 \mathrm{~mL})$ of 1,3-dimethyl-7H-purine-2,6-dione (Tp) (1.23-2.70 g) respectively were added to an aqueous solution of the metal salts. This is followed by the addition of an aqueous solution $(12 \mathrm{~mL})$ of KOCN $(0.47-0.96 \mathrm{~g})$ and an aqueous solution $(15 \mathrm{~mL})$ of $\mathrm{KSCN}(0.87-0.57 \mathrm{~g})$ respectively. After constant stirring using an appropriate amount of materials needed as decided by the molar ratio 1:2:2:1:1 (M:Tx:Tp:X:Y), the resulting precipitates were filtered off, washed several times and recrystallized with 1:3 ethanol: water mixture. Then, it was eventually dried in an oven at $65^{\circ} \mathrm{C}$.

\section{Results and Discussion}

Elemental analysis and melting point data obtained were in good agreement with the values calculated from the proposed empirical formula. The lower value observed of molar conductivities in DMSO indicates the non electrolyte behavior of the complexes ${ }^{8}$. Table 1 gives in details of the physical properties of the complexes.

\section{Infrared spectra studies}

\section{Infrared spectra of free ligands}

The spectrum of (Tp) shows strong bands at 3350, 1720 and $1668 \mathrm{~cm}^{-1}$ that may be attributed to the $v(\mathrm{NH}), v(\mathrm{C}=\mathrm{O})$ and $v(\mathrm{~N}=\mathrm{C})$ respectively. In addition, on complex formation 
the band of $\mathrm{C}=\mathrm{N}$ is shifted to the lower frequencies by $68-28 \mathrm{~cm}^{-1}$. The spectrum of $(\mathrm{Tx})$ exhibited a strong band at $1658 \mathrm{~cm}^{-1}$ which is attributed to the $v(\mathrm{~N}=\mathrm{C})$ is also shifted to lower wave number by $58-18 \mathrm{~cm}^{-1}$, all these shifted indicate that the $(\mathrm{C}=\mathrm{N})$ group is involved in complex formation. Furthermore, the spectra of the complexes exhibited weak bands between $500-545 \mathrm{~cm}^{-1}$ due to $v(\mathrm{M}-\mathrm{N})$. This indicates the coordination of Tx and Tp with metal ions through the nitrogen atom ${ }^{9-12}$.

Table 1. The physical properties of the prepared complexes

\begin{tabular}{|c|c|c|c|c|c|c|c|c|}
\hline \multirow[b]{2}{*}{ Compound } & \multirow[b]{2}{*}{ Color } & \multirow{2}{*}{$\underset{{ }^{\circ} \mathrm{C}}{\mathrm{M} . \mathrm{P}}$} & \multirow[b]{2}{*}{$\begin{array}{c}\text { Yield } \\
\%\end{array}$} & \multicolumn{4}{|c|}{ Elemental analysis, calc (found )\% } & \multirow{2}{*}{ ह } \\
\hline & & & & C & $\mathrm{H}$ & $\mathrm{N}$ & M & \\
\hline$\left[\mathrm{Co}(\mathrm{Tx})_{2}(\mathrm{Tp})_{2} \mathrm{XY}\right]$ & Pink & $>300$ & 70 & $\begin{array}{l}42.341 \\
(42.55)\end{array}$ & $\begin{array}{l}3.993 \\
(2.73)\end{array}$ & $\begin{array}{l}27.772 \\
(27.85)\end{array}$ & $\begin{array}{c}6.46 \\
(7.56)\end{array}$ & 15.62 \\
\hline$\left[\mathrm{Ni}(\mathrm{Tx})_{2}(\mathrm{Tp})_{2} \mathrm{XY}\right]$ & $\begin{array}{l}\text { Light } \\
\text { green }\end{array}$ & $>300$ & 65 & $\begin{array}{l}42.351 \\
(42.56)\end{array}$ & $\begin{array}{l}3.994 \\
(4.84)\end{array}$ & $\begin{array}{l}27.779 \\
(28.81)\end{array}$ & $\begin{array}{c}6.46 \\
(6.76)\end{array}$ & 21.12 \\
\hline$\left[\mathrm{Cu}(\mathrm{Tx})_{2}(\mathrm{Tp})_{2} \mathrm{XY}\right]$ & $\begin{array}{l}\text { Gray } \\
\text { green }\end{array}$ & $>300$ & 60 & $\begin{array}{l}42.127 \\
(42.14)\end{array}$ & $\begin{array}{l}3.973 \\
(3.57)\end{array}$ & $\begin{array}{l}27.632 \\
(27.79)\end{array}$ & $\begin{array}{c}6.66 \\
(7)\end{array}$ & 20.54 \\
\hline$\left[\mathrm{Zn}(\mathrm{Tx})_{2}(\mathrm{Tp})_{2} \mathrm{XY}\right]$ & white & $>300$ & 55 & $\begin{array}{l}42.042 \\
(41.11)\end{array}$ & $\begin{array}{l}3.965 \\
(3.64)\end{array}$ & $\begin{array}{l}27.576 \\
(27.92)\end{array}$ & $\begin{array}{l}7.13 \\
(8.3)\end{array}$ & 18.98 \\
\hline$\left[\mathrm{Cd}(\mathrm{Tx})_{2}(\mathrm{Tp})_{2} \mathrm{XY}\right]$ & white & $>300$ & 50 & $\begin{array}{l}39.985 \\
(39.93)\end{array}$ & $\begin{array}{l}3.771 \\
(3.83)\end{array}$ & $\begin{array}{l}26.228 \\
(26.43)\end{array}$ & $\begin{array}{l}11.66 \\
(12.3)\end{array}$ & 17.24 \\
\hline
\end{tabular}

The asymmetrical and symmetrical vibrations in $\mathrm{OCN}^{-}$were noticed at $2165 \mathrm{~cm}^{-1}$ and $1207 \mathrm{~cm}^{-1}$ respectively in the spectra of free ligand. These bands have already shifted to the higher frequencies by $35-75 \mathrm{~cm}^{-1}$ and $7-18 \mathrm{~cm}^{-1}$ respectively. Thus, the spectra of the complexes show bands in the range of $560-580 \mathrm{~cm}^{-1}$ which indicated that the cyanate ion was coordinated with the metal ions through the oxygen atom ${ }^{13-15}$.

The potassium thiocyanate spectrum showed a very strong band at $2048 \mathrm{~cm}^{-1}$ which belongs to the $v(\mathrm{CN})$. This band appeared in the complexes between $2050-2140 \mathrm{~cm}^{-1}$ which is shifted to the higher frequencies by $2-92 \mathrm{~cm}^{-1}$. Thus, the complexes exhibited weak bands between $415-440 \mathrm{~cm}^{-1}$ which are due to $\delta(\mathrm{M}-\mathrm{SCN})$. Therefore, the $\mathrm{SCN}^{-}$was coordinated with metal ions through the sulfur atom ${ }^{14,16}$. Table 2 gives the diagnostic absorptions and their assignments.

Table 2. The characteristic infrared absorptions of the prepared complexes

\begin{tabular}{cccccccccc}
\hline Compound & $v(\mathrm{NH})$ & $v(\mathrm{OCN})_{\text {asy }}$ & $v(\mathrm{CN})$ & $v(\mathrm{C}=\mathrm{N})$ & $v(\mathrm{OCN})_{\text {sy }}$ & $v(\mathrm{CS})$ & $\delta(\mathrm{M}-\mathrm{OCN})$ & $v(\mathrm{M}-\mathrm{N})$ & $\delta(\mathrm{M}-\mathrm{SCN})$ \\
\hline$\left[\mathrm{Co}(\mathrm{Tx})_{2}(\mathrm{Tp})_{2} \mathrm{XY}\right]$ & 3320 & 2220 & 2060 & 1600 & 1205 & 730 & 575 & 500 & 430 \\
{$\left[\mathrm{Ni}(\mathrm{Tx})_{2}(\mathrm{Tp})_{2} \mathrm{XY}\right]$} & 3340 & 2240 & 2080 & 1640 & 1225 & 740 & 560 & 535 & 440 \\
{$\left[\mathrm{Cu}(\mathrm{Tx})_{2}(\mathrm{Tp})_{2} \mathrm{XY}\right]$} & 3340 & 2200 & 2060 & 1620 & 1225 & 720 & 565 & 530 & 415 \\
{$\left[\mathrm{Zn}(\mathrm{Tx})_{2}(\mathrm{Tp})_{2} \mathrm{XY}\right]$} & 3340 & 2220 & 2140 & 1625 & 1225 & 740 & 560 & 535 & 430 \\
{$\left[\mathrm{Cd}(\mathrm{Tx})_{2}(\mathrm{Tp})_{2} \mathrm{XY}\right]$} & 3320 & 2200 & 2050 & 1630 & 1200 & 730 & 580 & 545 & 430 \\
\hline
\end{tabular}

\section{Magnetic susceptibility}

The magnetic moment for the complex of cobalt ion should be around 3.872 B.M while the measured value of $\mu_{\text {eff }}$ was shown to be higher than the expected value. This could be related to orbital-spin coupling ${ }^{17}$. However, the values of $\mu_{\text {eff }}$ of all $\mathrm{Ni}^{+2}$ and $\mathrm{Cu}^{+2}$ complexes were 
found to be closer to that of spinning only ${ }^{17}$. The complexes of $\mathrm{Zn}^{2+}, \mathrm{Cd}^{2+}$ were diamagnetic as expected from their electron configuration. The magnetic susceptibility data are presented in Table 3.

Table 3. The magnetic properties of the complexes at $25^{\circ} \mathrm{C}$

\begin{tabular}{|c|c|c|c|c|c|c|c|}
\hline \multirow[b]{2}{*}{ Complexes } & \multirow[b]{2}{*}{$\mathrm{d}^{\mathrm{n}}$} & \multirow{2}{*}{$\begin{array}{c}\text { Electron } \\
\text { configuration }\end{array}$} & \multirow{2}{*}{ 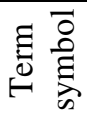 } & \multirow{2}{*}{$\begin{array}{l}\text { Groun } \\
\text { d state }\end{array}$} & \multicolumn{2}{|c|}{$\mu_{\text {eff }}$ B.M } & \multirow{2}{*}{$\begin{array}{c}\text { Orbital } \\
\text { contribution } \\
\text { in octahedral }\end{array}$} \\
\hline & & & & & Found & Calc. & \\
\hline$\left[\mathrm{Co}(\mathrm{Tx})_{2}(\mathrm{Tp})_{2} \mathrm{XY}\right]$ & $\mathrm{d}^{7}$ & $\mathrm{t}_{2} \mathrm{~g}^{5} \mathrm{eg}^{2}$ & ${ }^{4} \mathrm{~F}$ & ${ }^{4} T_{1} g$ & 4.258 & 3.872 & Yes \\
\hline$\left[\mathrm{Ni}(\mathrm{Tx})_{2}(\mathrm{Tp})_{2} \mathrm{XY}\right]$ & $d^{8}$ & $t_{2} g^{6} e^{2}$ & ${ }^{3} \mathrm{~F}$ & ${ }^{3} \mathrm{~A}_{2} \mathrm{~g}$ & 2.801 & 2.828 & No \\
\hline$\left[\mathrm{Cu}(\mathrm{Tx})_{2}(\mathrm{Tp})_{2} \mathrm{XY}\right]$ & $\mathrm{d}^{9}$ & $t_{2} g^{6} e^{3}$ & ${ }^{2} \mathrm{D}$ & ${ }^{2} \mathrm{Eg}$ & 1.683 & 1.732 & No \\
\hline$\left[\mathrm{Zn}(\mathrm{Tx})_{2}(\mathrm{Tp})_{2} \mathrm{XY}\right]$ & $\mathrm{d}^{10}$ & $t_{2} g^{6} e^{4}$ & ${ }^{1} S$ & & diamagnetic & Zero & - \\
\hline$\left[\mathrm{Cd}(\mathrm{Tx})_{2}(\mathrm{Tp})_{2} \mathrm{XY}\right]$ & $\mathrm{d}^{10}$ & $t_{2} g^{6} \mathrm{eg}^{4}$ & ${ }^{1} \mathrm{~S}$ & - & diamagnetic & Zero & - \\
\hline
\end{tabular}

Electronic spectral studies

The electronic spectra of the free ligands

The electronic spectra of the free ligand 1,3,7-trimethylxanthine (Tx) exhibited electronic transition $\pi \rightarrow \pi^{*}$ and $n \rightarrow \pi^{*}$ at 275, 316 and $365 \mathrm{~nm}$ respectively. The 1,3-dimethyl-7H-purine2,6-dione (Tp) has shown absorption bands at 274 and $340 \mathrm{~nm}$ due to electronic transitions $\pi \rightarrow \pi^{*}$ and $n \rightarrow \pi^{*}$ respectively ${ }^{18}$. The spectra of KSCN showed the electronic transitions of $\pi \rightarrow \pi^{*}$ and $n \rightarrow \pi^{*}$ at 276 and $360 \mathrm{~nm}$ respectively. The KOCN showed absorption bands at 272 and $300 \mathrm{~nm}$ which belong to the electronic transitions of $\pi \rightarrow \pi^{*}$ and $n \rightarrow \pi^{*}$ respectively.

\section{The electronic spectra of the complexes}

The Co(II) complex shows electronic transitions of ${ }^{4} \mathrm{~T}_{1} \mathrm{~g}_{(\mathrm{F})} \rightarrow{ }^{4} \mathrm{~A}_{2} \mathrm{~g}_{(\mathrm{F})}$ at $280 \mathrm{~nm}$, ${ }^{4} \mathrm{~T}_{1} \mathrm{~g}_{(\mathrm{F})} \rightarrow{ }^{4} \mathrm{~T}_{1} \mathrm{~g}_{(\mathrm{P})}$ at $429 \mathrm{~nm}$ and ${ }^{4} \mathrm{~T}_{1} \mathrm{~g}_{(\mathrm{F})} \rightarrow{ }^{4} \mathrm{~T}_{2} \mathrm{~g}_{(\mathrm{F})}$ at 904 and $990 \mathrm{~nm}$ respectively. The electronic spectrum of $\mathrm{Ni}(\mathrm{II})$ complex exhibited absorption bands at $284 \mathrm{~nm}$ and $389 \mathrm{~nm}$ which are attributed to the electronic transitions ${ }^{3} \mathrm{~A}_{2} \mathrm{~g}_{(\mathrm{F})} \rightarrow{ }^{3} \mathrm{~T}_{1} \mathrm{~g}_{(\mathrm{P})}$ and ${ }^{3} \mathrm{~A}_{2} \mathrm{~g}_{(\mathrm{F})} \rightarrow{ }^{3} \mathrm{~T}_{1} \mathrm{~g}_{(\mathrm{F})}$ respectively. It is also appeared in the visible region bands at 807 and $986 \mathrm{~nm}$ respectively which are attributed to the electronic transition as ${ }^{3} \mathrm{~A}_{2} \mathrm{~g}_{(\mathrm{F})} \rightarrow{ }^{3} \mathrm{~T}_{2} \mathrm{~g}_{(\mathrm{F})}$. The $\mathrm{Cu}(\mathrm{II})$ complex exhibited band in the visible region which is attributed to the electronic transition ${ }^{2} \mathrm{Eg} \rightarrow$ ${ }^{2} \mathrm{~T}_{2} \mathrm{~g}$ which splitted into two bands as ${ }^{2} \mathrm{~b}_{2} \mathrm{~g}_{(\mathrm{D})} \rightarrow{ }^{2} \mathrm{~b}_{1} \mathrm{~g}_{(\mathrm{D})}$ and ${ }^{2} \mathrm{eg}(\mathrm{D}) \rightarrow{ }^{2} \mathrm{~b}_{1} \mathrm{~g}_{(\mathrm{D})}$ at 567 and $777 \mathrm{~nm}$ respectively ${ }^{19}$. Finally, $\mathrm{Zn}(\mathrm{II})$ and Cd(II) complexes with an electronic configuration of $\left(\mathrm{d}^{10}\right)$ did not show any (d-d) transitions. Instead the absorption bands in the spectra were due to charge transfer transitions which suffered from red and blue shift with hyper chromic effect ${ }^{19-21}$. These absorptions were fully assigned in Table 4 .

Table 4. UV Visible spectra of free ligands and their complexes $10^{-3} \mathrm{M}$ in DMSO

\begin{tabular}{cccccc}
\hline Compound & $\begin{array}{c}\lambda_{\max } \\
\mathrm{nm}\end{array}$ & ABS & $\begin{array}{c}\text { Wave number } \\
\mathrm{cm}^{-1}\end{array}$ & $\begin{array}{c}\varepsilon_{\max } \\
\mathrm{Lmol}^{-1} \mathrm{~cm}^{-1}\end{array}$ & assignment \\
\hline \multirow{3}{*}{ Tx } & 275 & 1.774 & 36363 & 1774 & $\pi \rightarrow \pi^{*}$ \\
& 316 & 0.006 & 31645 & 6 & $\mathrm{n} \rightarrow \pi^{*}$ \\
& 365 & 0.014 & 27397 & 14 & $\mathrm{n} \rightarrow \pi^{*}$ \\
Tp & 274 & 1.728 & 36496 & 1728 & $\pi \rightarrow \pi^{*}$ \\
KSCN & 340 & 0.554 & 29411 & 544 & $\mathrm{n} \rightarrow \pi^{*}$ \\
& 276 & 0.529 & 36231 & 529 & $\pi \rightarrow \pi^{*}$ \\
& 360 & 0.329 & 27777 & 329 & $\mathrm{n} \rightarrow \pi^{*}$ \\
\hline
\end{tabular}




\begin{tabular}{|c|c|c|c|c|c|}
\hline \multirow[t]{2}{*}{ KOCN } & 272 & 0.614 & 36764 & 614 & $\pi \rightarrow \pi_{*}$ \\
\hline & 300 & 0.125 & 33333 & 125 & $\mathrm{n} \rightarrow \pi_{*}$ \\
\hline \multirow[t]{4}{*}{$\left.\mathrm{Co}(\mathrm{Tx})_{2}(\mathrm{Tp})_{2} \mathrm{XY}\right]$} & 280 & 1.883 & 35714 & 1883 & ${ }^{4} \mathrm{~T}_{1} \mathrm{~g}_{(\mathrm{F})} \rightarrow{ }^{4} \mathrm{~A}_{2} \mathrm{~g}_{(\mathrm{F})}\left(\mathrm{v}_{2}\right)$ \\
\hline & 429 & 0.017 & 23310 & 17 & ${ }^{4} \mathrm{~T}_{1} \mathrm{~g}_{(\mathrm{F})} \rightarrow{ }^{4} \mathrm{~T}_{1} \mathrm{~g}_{(\mathrm{P})}\left(\mathrm{v}_{3}\right)$ \\
\hline & 904 & 0.005 & 11061 & 5 & ${ }^{4} \mathrm{~T}_{1} \mathrm{~g}_{(\mathrm{F})} \rightarrow{ }^{4} \mathrm{~T}_{2} \mathrm{~g}_{\mathrm{F})}\left(v_{1}\right)$ \\
\hline & 990 & 0.022 & 10101 & 22 & $\mathrm{~T}_{1} \mathrm{~g}_{(\mathrm{F})} \rightarrow \mathrm{T}_{2} \mathrm{~g}_{(\mathrm{F})}\left(\mathrm{V}_{1}\right)$ \\
\hline \multirow[t]{4}{*}[\mathrm{Ni}(\mathrm{Tx})_{2}(\mathrm{Tp})_{2}\mathrm{XY}]{} & 284 & 1.948 & 35211 & 1948 & ${ }^{3} \mathrm{~A}_{2} \mathrm{~g}_{(\mathrm{F})} \rightarrow{ }^{3} \mathrm{~T}_{1} \mathrm{~g}_{(\mathrm{P})}\left(\mathrm{v}_{3}\right)$ \\
\hline & 389 & 0.025 & 25706 & 25 & ${ }^{3} \mathrm{~A}_{2} \mathrm{~g}_{(\mathrm{F})} \rightarrow{ }^{3} \mathrm{~T}_{1} \mathrm{~g}_{(\mathrm{F})}\left(\mathrm{v}_{2}\right)$ \\
\hline & 807 & 0.003 & 12391 & 3 & ${ }^{3} \mathrm{~A}_{2} \mathrm{~g}_{(\mathrm{F})} \rightarrow{ }^{3} \mathrm{~T}_{2} \mathrm{~g}_{(\mathrm{F})}\left(\mathrm{v}_{1}\right)$ \\
\hline & 986 & 0.009 & 10141 & 9 & \\
\hline \multirow[t]{3}{*}[\mathrm{Cu}(\mathrm{Tx})_{2}(\mathrm{Tp})_{2}\mathrm{XY}]{} & 290 & 2.192 & 34482 & 2192 & $(\mathrm{C}-\mathrm{T})$ \\
\hline & 567 & 0.038 & 17636 & 38 & ${ }^{2} b_{2} g_{(D)} \rightarrow{ }^{2} b_{1} g_{(D)}\left(v_{2}\right)$ \\
\hline & 777 & 0.070 & 12870 & 70 & ${ }^{2} \mathrm{eg}_{(\mathrm{D})} \rightarrow{ }^{2} \mathrm{~b}_{1} \mathrm{~g}_{(\mathrm{D})}\left(\mathrm{v}_{1}\right)$ \\
\hline$\left[\mathrm{Zn}(\mathrm{Tx})_{2}(\mathrm{Tp})_{2} \mathrm{XY}\right]$ & 277 & 1.743 & 36101 & 1743 & Charge transfer $\mathrm{M} \rightarrow \mathrm{L}$ \\
\hline \multirow[t]{3}{*}[\mathrm{Cd}(\mathrm{Tx})_{2}(\mathrm{Tp})_{2}\mathrm{XY}]{} & 279 & 1.892 & 35842 & 1892 & Charge transfer $\mathrm{M} \rightarrow \mathrm{L}$ \\
\hline & 321 & 0.014 & 31152 & 14 & $\begin{array}{l}\text { Red shift with hyper } \\
\text { chromic effect }\end{array}$ \\
\hline & 345 & 0.027 & 28985 & 27 & $\begin{array}{l}\text { Blue shift with hyper } \\
\text { chromic effect }\end{array}$ \\
\hline
\end{tabular}

\section{Conclusion}

The interaction of 1,3,7-trimethylxanthine and 1,3-dimethyl-7 $\mathrm{H}$-purine-2,6-dione with metal ions to yield mixed ligand complexes of $\left[\mathrm{M}(\mathrm{Tx})_{2}(\mathrm{TP})_{2} \mathrm{XY}\right]$ where $\mathrm{M}=\mathrm{Co}(\mathrm{II}), \mathrm{Ni}(\mathrm{II}), \mathrm{Cu}(\mathrm{II})$, $\mathrm{Zn}(\mathrm{II})$ and $\mathrm{Cd}(\mathrm{II}), \mathrm{Tx}=1,3,7$-trimethylxanthine, $\mathrm{Tp}=1,3$-dimethyl-7H-purine-2,6-dione, $\mathrm{X}=\mathrm{SCN}$ and $\mathrm{Y}=\mathrm{OCN}$ was investigated. As part of our studies on the chemistry of transition metal ions and magnetic properties, we were able to investigate the paramagnetic properties of the $\mathrm{Co}(\mathrm{II}), \mathrm{Ni}(\mathrm{II})$ and $\mathrm{Cu}(\mathrm{II})$ complexes and the diamagnetic for $\mathrm{Zn}$ (II) and $\mathrm{Cd}$ (II) complexes. The molar conductivity of complexes in DMSO solution was non-electrolyte. However, the configuration of the complexes was confirmed that the $\mathrm{Tx}$ and $\mathrm{Tp}$ were coordinated with metal ions through the nitrogen atom, while, the metal ions were coordinated with $\mathrm{SCN}^{-}$ through the sulfur atom. However, the OCN was coordinated with metal ions through the oxygen atom. Therefore, it can be concluded from the presented results that the complexes have octahedral configuration, as shown in Figure 1.

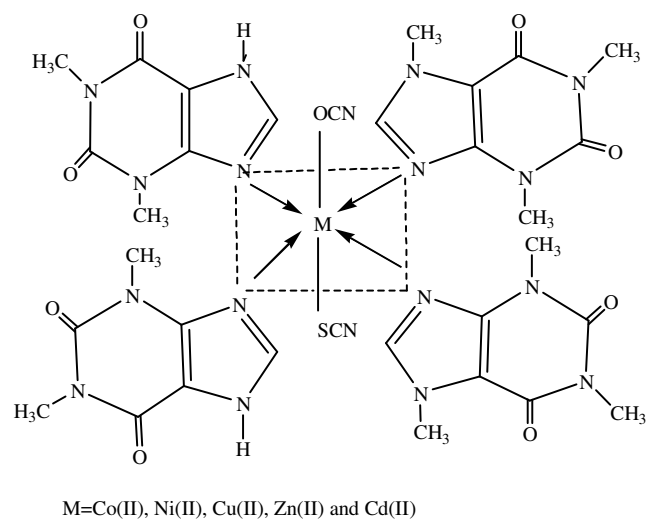

Figure 1. Structure of the prepared complexes $\left[\mathrm{M}(\mathrm{Tx})_{2}(\mathrm{Tp})_{2} \mathrm{XY}\right]$ 


\section{Acknowledgment}

Thanks are due to the Chemistry Department at College of Ibn-Alhaitham of Education, Baghdad University, Iraq. Additional thanks are due to Dr. Sadia Mahmoud and Dr. Hussein A. Mohammed for them kind help.

\section{References}

1. Colacio R E, lopez J D and Salas J M, Can J Chem., 1983, 61, 2506-2508.

2. Francesco V R, Ole A A, Kalpit A V, Julie A D, Daan M F and Van A, Chem Biol., 2005, 12, 973-980.

3. Paul A W, Frances M and Zoltan S, Psychopharm., 1998, 136, 264.271.

4. Thuanny F, Muriel A and Reinaldo S G, Appl Surface Sci., 2006, 253, 566-571.

5. Esimone C O, Okoye F B C, Nworu C S and Agubata C O, Tropical J Pharm Res., 2008, 7, 969-974.

6. $\quad$ Bojidarka I, Turk J Chem., 2007, 31, 97-103.

7. Gordon W B, Roderick J D, Keith R D and Arthurc C R, Can J Chem., 1983, 61, 1132-1141.

8. Kettle S F A, Coordination Compounds; Thomas Nelson and Sons: London, 1975, 165.

9. Cross A D and Alan R J, An Introduction to Partical Infrared Spectroscopy; $3^{\text {ed }}$ Ed., Butterworth: London, 1969.

10. John D R, Application of Absorption Spectroscopy of Organic Compounds; PrenticeHall: New Jersey, 1965.

11. William and Fleming, Spectroscopic Methods in Organic Chemistry; $2^{\text {nd }}$ Ed., McGraw-Hill: London, New York, 1973.

12. Shayma A S and Yang F, Am J Sci Res., 2009, 5, 20-26.

13. Bailey R A and Kozak S L, J Inorg Nucl Chem., 1969, 31, 689-693.

14. Kazuo N, Infrared and Raman Spectra of Inorganic and Coordination Compounds; $5^{\text {th }}$ Edn., John Wiley and sons, Inc: New York, 1997.

15. Socrates G, Infrared Characteristic Group Frequencies; Wiley-Interscience publication: New York, 1980.

16. Michael B and Rudolf H, J Electron Anal Chem., 1995, 385, 105-113.

17. David N, Complexes and First Row Transition Elements; American Elsevier, 1984.

18. Satwinder S M, Jasjest K and Gurvinder S S, Met Based Drugs., 1995, 2(1), 13-17, doi: 10.1155/MBD.

19. Lever A B P, Inorganic Electronic Spectroscopy; Elsevier publishing Co. Ltd: New York, 1968.

20. Monther Y, The Physical Methods in Inorganic Chemistry; Baghdad University press: Iraq, 1983.

21. Russell S D, Physical Methods in Inorganic Chemistry; Van Nostrand Reinhold Inc: U.S, 1965, ISBN-10: 0278920667. 


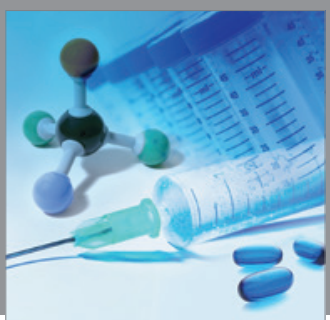

International Journal of

Medicinal Chemistry

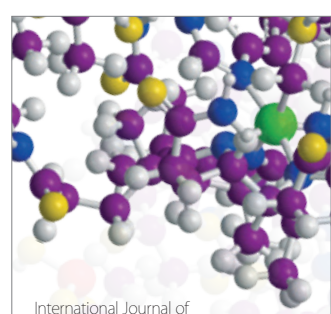

Carbohydrate Chemistry

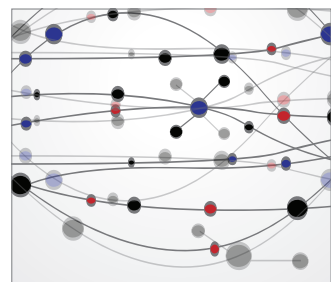

The Scientific World Journal
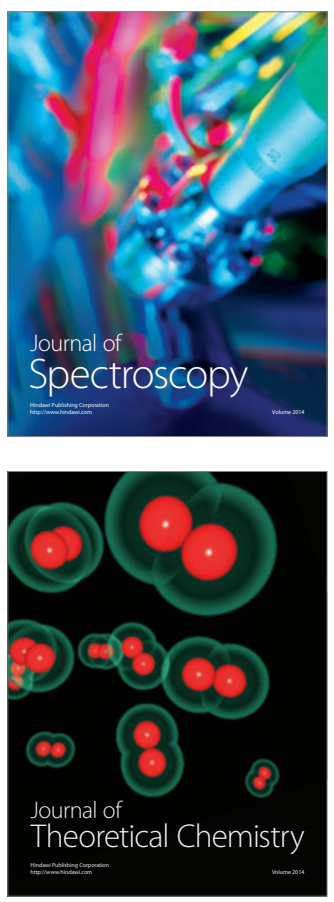
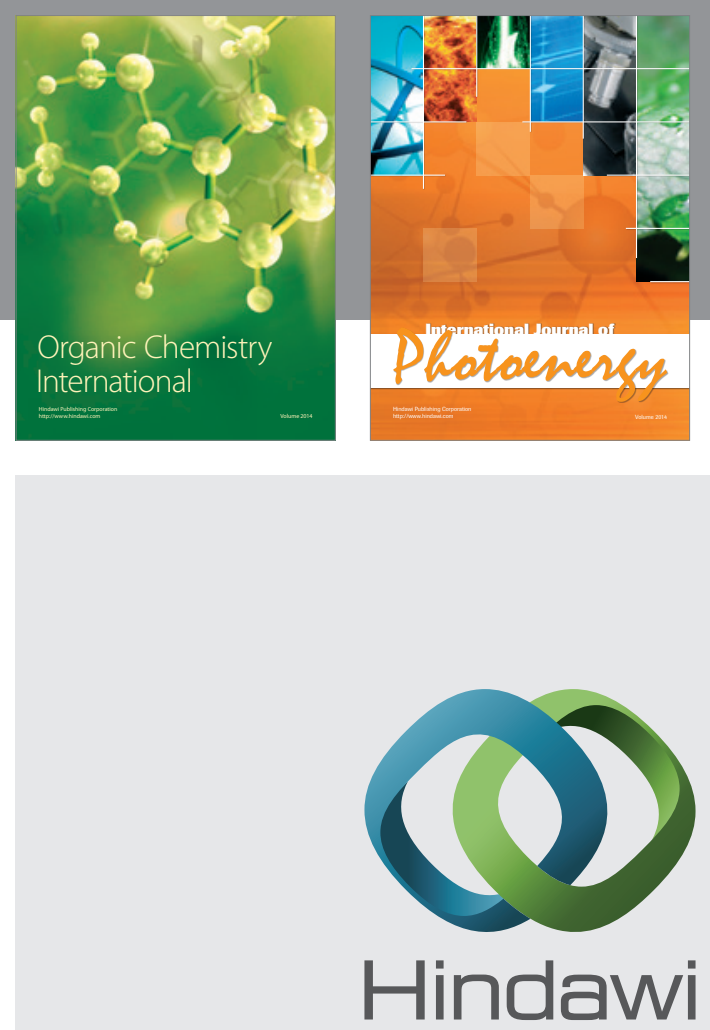

Submit your manuscripts at

http://www.hindawi.com
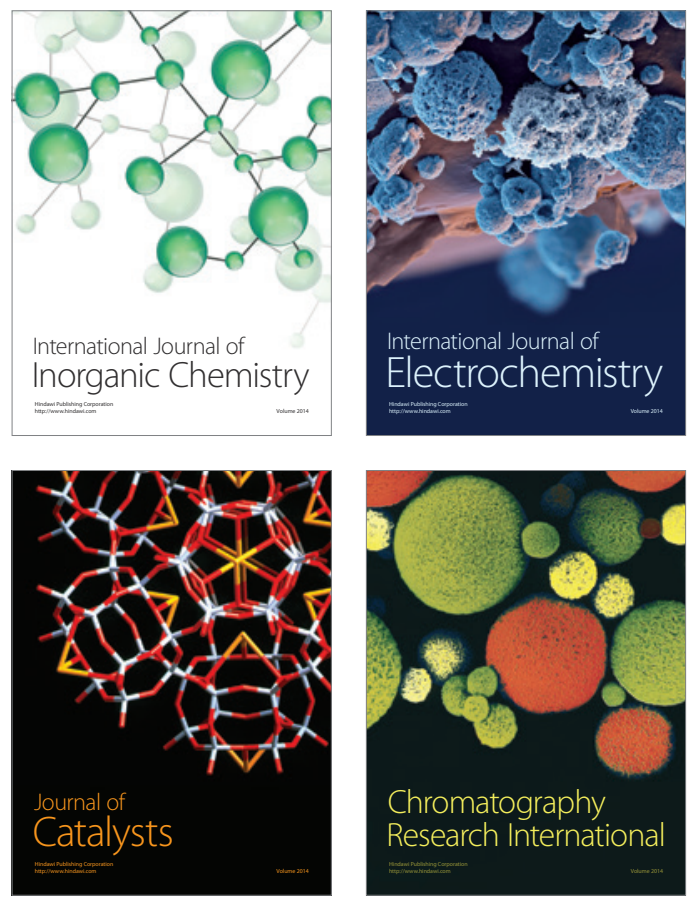
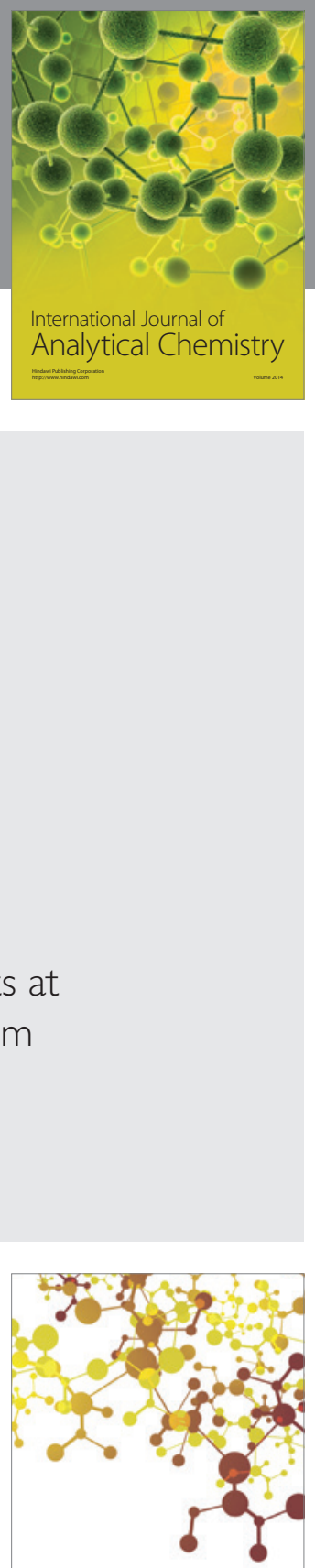

Journal of

Applied Chemistry
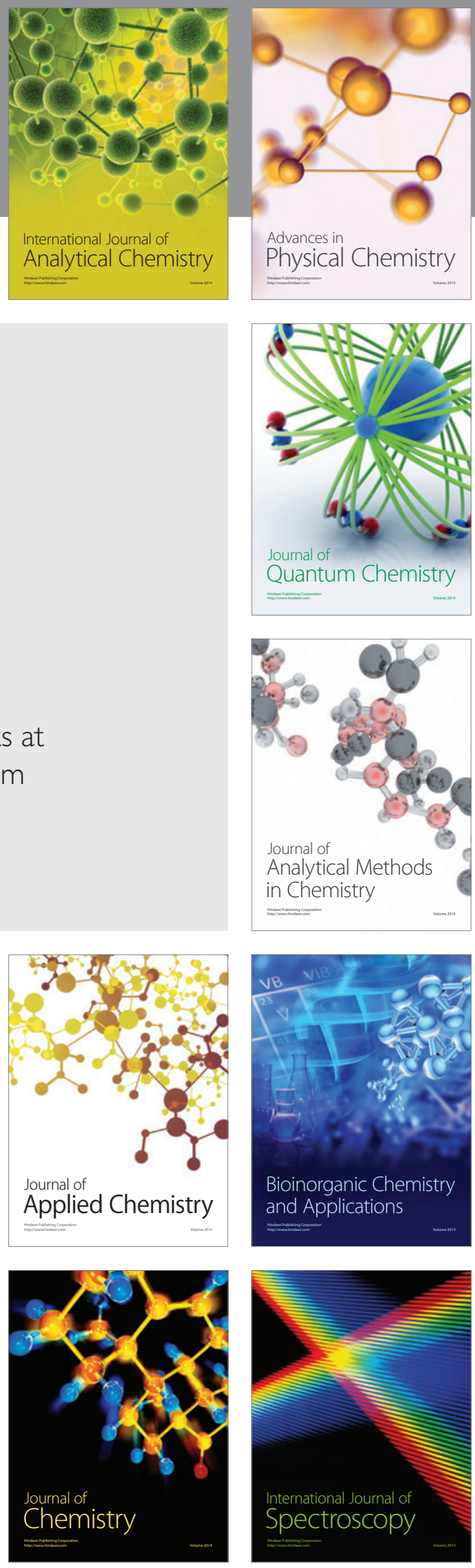